\title{
Home Care Caregivers Knowledge about Infections Related to Health Care \\ ORIGINAL
}

\author{
Lucélia Campelo de Melo Santos', Luana Kelle Batista Moura², \\ Andréia Rodrigues Moura da Costa Valle ${ }^{3}$, Gerardo Vasconcelos Mesquita ${ }^{4}$, \\ Lucíola Galvão Godim Correa Feitosa ${ }^{5}$
}

\section{Abstract}

Objective: Analyze the knowledge of home caregivers about health care related infections.

Method: Descriptive and exploratory research, with qualitative approach, conducted with 75 caregivers of patient hospitalized at home. The data was collected through a semi-structured interview script, from August to September, 2016, processed on the IRAMUTEQ software and analyzed by the descending hierarchical classification.

Results: The results were presented with two axis: Axis 1. Risk factors that contribute to the home infection by the caregiver point of view, containing the classes; Class 3. Sanitation and caring with the food in the home ambient; Class 4. Home ambient cleaning; Class 5. The handling of patient with infection risks; Class 6. Cares on the prevention of infections in the home ambient; Axis 2. The concept of home infection to the caregiver, containing the classes; Class 1. The knowledge about the disease on the daily routine; Class 2 . The concept of the infection based on the dirtiness and on the disease.

Conclusion: The home care caregivers showed to know the relation between the lack of sanitation in the ambient and the infected food. In this sense, the caregivers recognize that the risks which their patient are exposed. They report the disease and the dirtiness as inherent to the infection concept and recognize the lack of security and quality in its practice.
1 Nurse. Professional MSc in Family Health, UNINOVAFAPI. Teresina, Piauí, Brazil.

2 Dentist, Doctor. Professional MSc in Family Health, UNINOVAFAPI. Teresina, Piauí, Brazil.

3 Nurse,Doctor. PostgraduateProgram in Nursing. Federal University of Piauí, UFPI. Teresina, Piauí, Brazil.

4 Physician, Doctor. Professional MSc in Family Health, UNINOVAFAPI. Teresina, Piauí, Brazil.

5 Nurse, Doctor. Professional MSc in Family Health, UNINOVAFAPI. Teresina, Piauí, Brazil.

Contact information:

Lucélia Campelo de Melo Santos.

Address: 4209, Monsenhor JoséLuiz Cortez street, Santa Isabel, Teresina-Piauí, 64.053-090.

Tel: (86) 99974-5318.

झ lucellyacampello@yahoo.com.br 


\section{Introduction}

In Brazil, with the health assistance profile, the hospital hospitalization time can be reduced. With the patient transference from the hospital to his home, increases the proximity with the family and can consequently decrease the emotional stress and collaborate to the good clinical evolution. However, even with the hospital ambient leaving to the home ambient, the infection risks are still high if there aren't prevention measures.

The Ministry of Health of Brazil , through the concierge number 963 from May 2013, concepts the home care as a new modality of the health care, substitutive or complementary to the existents promoting the treatment and the rehabilitation, managing the Multi professional Home Care Teams (MHCT) and without familiar bond to the user, capable to help him in his necessities and daily life activities [1].

According to the Health Ministry, the home care aims the work process reorganization of the teams that provides home care on the basic care, outpatient, on the urgency and emergence hospital services, aiming to decrease the demand for hospital attendant and/or reduction of the permanence period of the hospitalized users, the humanization care, the deinstitutionalization and the users autonomy spread [1].

Infections related to care represent a serious public health problem due to high morbidity and mortality [2]. The main problem is patient contamination during care. Caregivers may also be exposed to infected patients during care [3].

The infections related to the health assistance more prevalent are: respiratory, urinary tract, skin infections and parasitic diseases, being the extremes ages determinants factors to the infection due to their immunologic system fragility. This fact associated to chronic diseases turns the situation even more serious [4].

However, the infection prevention related to the health assistance is directly related to the caregivers' skills and abilities worked in continuously education programs. There is a scarcity of studies about the caregivers' knowledge and training to make, with safety and quality, the patient assistance.

The care quality through the patient perspective, specially on the home health care, started to be investigated very recently [5]. The caregiver assumes the responsibility to take care, however, in the most part of the times he didn't receive any kind of prepare to this situation, acquiring experience by the tentative and mistakes, by the repetition or informal orientations of the adjacent community [6].

Among the cared individuals, there is a high dependence level, situation grieved by the enteral diet use, through nasogastric tube, gastronomy or jejunostomy, tracheostomy with the necessity of aspiration and oxygen therapy [7].

Thereby, the family shall assume to themselves the responsibility to conduct complex procedures and cares, previously conducted by health professionals and never before by the care givers, what can result in injury to the cared individual [1].

From this problematic, the study aim to analyze the knowledge of home caregivers about health care related infections.

\section{Methods}

It is about an exploratory and descriptive research with qualitative approach, conducted with 75 patient's caregivers hospitalized at home and companied with the Multiprofessional Home Care Team (MHCT), of an urgency hospital in Teresina, Piauí, Brazil.

The data were collected through a semi-structured interview script, recorded with the help of an MP4 device, with ten open questions, from August to September 2016, in an environment reserved for participants' privacy after signing of the Term of Consent. The interviews had an average duration of 30 minutes. The inclusion criteria to participate in the study were: to be a caregiver of a previously 
Figure 1: Dendrogram of classes derived from the corpus. ECU: elementary context units.

\begin{tabular}{|c|c|c|c|c|c|c|c|c|c|c|c|}
\hline & \multicolumn{4}{|c|}{$\begin{array}{l}\text { Axis } 1 \\
\text { Risk factors that contribute to the home } \\
\text { infection by the caregiverpoint ofview }\end{array}$} & \multicolumn{4}{|c|}{$\begin{array}{c}\text { Axis } 2 \\
\text { The concept of home infection to the caregiver }\end{array}$} & & \\
\hline \multirow{2}{*}{\multicolumn{2}{|c|}{ Class 3}} & 7 & & \multirow{2}{*}{\multicolumn{2}{|c|}{ Class 5}} & & & \multirow{2}{*}{\multicolumn{2}{|c|}{ Class 1}} & & \\
\hline & & \multicolumn{2}{|c|}{ Class 4} & & & \multicolumn{2}{|c|}{ Class 6} & & & \multicolumn{2}{|c|}{ Class 2} \\
\hline \multicolumn{2}{|c|}{12 ECU $17.6 \%$} & \multicolumn{2}{|c|}{10 ECU $14,7 \%$} & \multicolumn{2}{|c|}{12 ECU $15.79 \%$} & \multicolumn{2}{|c|}{14 ECU $20.5 \%$} & \multicolumn{2}{|c|}{10 ECU $14.7 \%$} & \multicolumn{2}{|c|}{10 ECU $14.7 \%$} \\
\hline \multirow{2}{*}{\multicolumn{2}{|c|}{$\begin{array}{l}\text { Sanitation and caring } \\
\text { with the food in the } \\
\text { home ambient }\end{array}$}} & \multicolumn{2}{|c|}{ Home ambient cleaning } & \multirow{2}{*}{\multicolumn{2}{|c|}{$\begin{array}{l}\text { The patient handling as } \\
\text { the infection cause }\end{array}$}} & \multirow{2}{*}{\multicolumn{2}{|c|}{$\begin{array}{c}\text { Cares on the prevention } \\
\text { of infections at the home } \\
\text { ambient }\end{array}$}} & \multirow{2}{*}{\multicolumn{2}{|c|}{$\begin{array}{c}\text { The disease related to the } \\
\text { daily routine }\end{array}$}} & \multirow{2}{*}{\multicolumn{2}{|c|}{$\begin{array}{l}\text { The concept of the } \\
\text { infection based on the } \\
\text { dirtiness }\end{array}$}} \\
\hline & & Word & $x^{2}$ & & & & & & & & \\
\hline Word & $x^{2}$ & $\begin{array}{l}\text { Clean } \\
\text { Toilet }\end{array}$ & $\begin{array}{l}20.0 \\
11.2\end{array}$ & $\begin{array}{l}\text { Word } \\
\text { Purchase }\end{array}$ & $\begin{array}{c}X^{2} \\
25.1\end{array}$ & Word & $x^{2}$ & $\begin{array}{l}\text { Word } \\
\text { Disease }\end{array}$ & $\begin{array}{c}X^{2} \\
19.1\end{array}$ & Word & $x^{2}$ \\
\hline Sanitation & 31.3 & $\begin{array}{l}\text { Toilet } \\
\text { Search }\end{array}$ & $\begin{array}{l}11.2 \\
6.7\end{array}$ & Cause & 19.8 & Local & 20.5 & Understand & 9.0 & Much & 38.1 \\
\hline Wash & 29.4 & Hygienic & 6.7 & Infection & 10.6 & List & 12.1 & Anything & 8.8 & Dirty & 12.3 \\
\hline Eat & 19.8 & Bad & 6.7 & Handling & 9.6 & sanitize & 11.5 & Hour & 6.7 & Prevent & 9.0 \\
\hline Food & 12.0 & Hand & 4.5 & Object & 9.6 & Residence & 6.3 & Stay & 6.7 & Thing & 6.7 \\
\hline Hand & 8.9 & Prevent & 3.7 & Patient & 7.5 & Patient & 4.4 & Find & 6.7 & Bad & 6.7 \\
\hline Sheet & 5.1 & wash & 3.3 & Hygiene & 6.2 & Meet & 4.0 & Feed & 4.2 & To know & 3.7 \\
\hline Take & 5.1 & Cleaning & 2.3 & Home & 5.8 & Everything & 2.7 & No & 2.8 & Take & 2.8 \\
\hline Prevention & 4.7 & Environment & 2.0 & exchange & 5.1 & Care & 2.7 & Bath & 2.7 & No & 2.8 \\
\hline Always & 4.4 & & & Belongs & 5.1 & When & 2.7 & To leave & 2.7 & To leave & 2.7 \\
\hline Good & 3.9 & & & Corporal & 5.1 & Dirt & 2.2 & & & Care & 2.1 \\
\hline & & & & Environment & 5.1 & Keep & 2.2 & & & Caution & 2.0 \\
\hline & & & & Bacterium & 3.0 & & & & & & \\
\hline & & & & Contact & 3.0 & & & & & & \\
\hline & & & & Care & 2.1 & & & & & & \\
\hline
\end{tabular}


hospitalized patient in the emergency hospital in Teresina, Piauí, Brazil and to be over 18 years old. The exclusion criteria were: to be a caregiver away from their activities and on vacation.

The data were processed through the IRAMUTEQ software (Interface de R pour les Analyses Multimensionnelles de Texteset de Questionnaires). The texts were transcribed following command lines, always before each content, aiming to separate each Initial Context Unit (ICU) or interview. Those groups of texts created the analyzed corpus [8].

Posteriorly, the program conducted the corpus division, based on the occurrence of the words in function to its roots and proceeded the frequency calculus of those forms conducted to obtain the produced classes significance. To obtain the classes, was applied the descending hierarchical rank method, that is the relation between classes, using the chi-square test $\left(x^{2}\right)$ on the reduced forms.

The research was approved by the Research Ethics Committee from the UNINOVAFAPI university center, with the protocol number 58950816.6.0000.5210.

\section{Results and Discussion}

The IRAMUTEQ recognized that the corpus separation in 73 elementary text unities (ECU), from 93 texts segments. Were registered 2762 occurrences, with profit of $73.12 \%$ of the total corpus. The classified segments were divided in 06 classes, according to the dendogram represented on the Figure 1, with occurrence percentage and value of $X^{2}$ most elevated of the classes.

The results were presented in 2 axis, Axis 1. Risk factors that contribute to the home infection by the caregiver point of view, containing 4 classes and the Axis 2. The concept of home infection to the caregiver, containing 2 classes.

Through the descending hierarchical rank method, were possible the textual domain iden- tification and analyzes, and also significant interpretation, giving them names with their respective senses in classes, as presented on the Table 1 below.

\section{Axis 1. Risk factors that contribute to the home infection by the caregiver point of view}

\section{Class 3: Sanitation and caring with the food in the home ambient}

With $12 \mathrm{ECU}$, that corresponds to $17.6 \%$ of the total corpus and it directly associated to classes 4, 5 and 6 . The words (sanitation, cleaning, eat and food) were selected by the frequency and values of $\mathrm{X}^{2}$ more elevated in this class.

The main risk factors that contribute to infections on the home hospitalization according to the speeches extracted by the caregivers were related according to the ambient sanitation and the food: sanitation, cleaning, and food. The recognition from the layman caregivers of the relation between the sanitation and food is of great important to the adhesion to process of secure care, when associated to future infection prevention.

Be careful with the patient; be careful with the food cleaning, ambient cleaning, etc. wash the hand when deal with food, clean the dishes when cleaned, using gloves and sanitize the ambient.

Ind.36.

Always be clean, be careful when eating the food, cleaning it before the consumption, walking always with something on the feet when entering in the bathroom, and wash the hands in all the meals.

Ind.37.

Be hygienic with the hand, always wash the food before the consumption, cleaning, and wash always the hand before eating.

Ind.43. 
The ingestion of contaminated food can result in diseases or even outbreaks. In 2003, epidemiological data from the USA revealed that 76 millions of people got sick per food intoxication, resulting in 325,000 hospitalizations and 5,000 deaths per year [9].

In Brazil it is estimated 6320 deaths per year, caused infection, according to the Information System about mortality. This fact impacts in high spent to the public system with hospitalization and establishes the promotion necessity for a sanitary public policy as IRA's prevention.

The food contamination reflects directly on the hygiene precarious conditions at the storage, prepare and handling of those in home ambient [10]. The implementation of infection prevention and control strategies, including the decontamination appropriate on superficies, stops the transmission range and reinforce the necessity to approach the ambient factors on the infections prevention [11].

\section{Class4: Home ambient cleaning}

With 10 ECU, what correspond to $14.7 \%$ of the total corpus, and is directly associated with the classes 5 and 6 . The words (clean, bathroom, try, hygienic) were selected by the frequency and values of $x^{2}$ most elevated in this class.

The knowledge extracted from this class shows that the caregiver understands that he needs to know how to sanitize the ambient to a secure care, free of infection. They highlighted the concerning in keep the ambient and house containing clean and mainly the patient clean. Thus they established a relation between the ambient and the sanitation measures to the infection control at the home hospitalization.

Try to handle the objects as also the patient always with cleaned and sanitized hands and also the clean ambient.

Ind.49.
Prevent and maintain always the ambient clean and have the hygienic care with the patient, always cleaning.

Ind.68.

The inability to maintain the ambient clean, to clean the sink, bathroom and glasses, try to clean the ambient.

Ind.71.

The infections can be transmitted out of the hospital ambient, it is, they are present in everywhere, even where the activities about the health assistance are in low complexity, as the home ambient, what results in risk factors, as the sanitation, precarious hygienic, food unduly adequate, home garbage collection and other vectors containing microorganisms capable to promote infections [12].

The principal exogenous factors are the low adhesion to the hands sanitation and ambient cleaning, and they present direct influence on the infection acquisition [13].

The cleaning processes, ambient disinfection and continuous intervention on the dynamic use of educational measures are used to intervene on the microorganisms' control. Thereby the knowledge of the relation between the superficies of the diseases transmission range, in special, the ones with direct contact to the patient as the bed, turns relevant by the necessity of strategies to the IRAS control [14].

The main objective of the IRAS prevention is to protect the patient, the health worker and other people in the health assistance ambient, as the home caregivers. They are part of the group components essential of measures implemented to the hand sanitation, the care with the physical area and the ambient care [15].

\section{Class 5: The patient handling as the infection cause}

With 12 ECU, that corresponds to $15.79 \%$ of the total corpus, and is directly associated to class 6 . 
The words (acquire, cause, infection, handling) were selected by the frequency and values of $x^{2}$ more elevated in this class.

In this class is understood that the caregivers establish a relation between way of handling the belongings inserted on the home ambient and the lack of sanitation that can promote a home infection. The care and handling are responsible for the main cause of IRAS on the moment of the patient assistance.

The home infection can be the condition grievance of the patient who is being treated and accompanied at home and can be related to the lack of adecquated care and or handling administration of material to the patient condition.

Ind.39.

The patient contagious or contamination can be occasioned by the clack of care with the sanitation during their belongings, food, bath handling. We must keep the house and all objects clean. Sanitize with alcohol 70 percent or purified water solution and sanitary water.

Ind.49.

Acquire infection at the patient home is avoid to create eschar and have all the hygienic care and in food, as well as to use the equipments, change all the bed cloths and daily make the body hygiene. Ind.60.

The occupational risks on the home care represent an area needy for investments mainly on the prevention of cross infection and or accidents. This include to explore the standard precautions that must be applied on the attendance to all the patients, in the presence of a contact risk with blood; body flawed; secretions and excretions; skin with continuity solution; and mucous [16].

In a study conducted with the home caregivers in a home care service, the presented results proves that all the caregivers conducted the hand hygiene before conducting the procedure, being that some of them used water and soap while others used only water as a hygiene way [17]. It is observed the needy of a more expressive orientation about the hand hygiene focusing on the right technique, and also work the orientations by the caregiver view, due to a hard adhesion to the hygiene protocols and the not relevance about its importance.

Authors relate about the main measures to the equipment or articles hygiene. It is recommend using detergent and water to a medium disinfection, or even the sodium hypochlorite in $1 \%$ per 10 minutes using, after we shall proceed the drying with a clean cloth. It is also recommended the use of alcohol $70 \%$ to disinfection in low level in equipments as stand or even beds [18].

The equipments use to individual protection shall be used always that anticipates the risk of contact to blood splash or other matter and shall be largely available, being them: gloves, facial masks (common surgical), waterproof apron, protection glasses [19]. The alcohol gel using on the hands hygiene and consequently contributes to the infection rates [20].

\section{Class 6: Cares on the prevention of infections at the home ambient}

With 14 ECU, that corresponds to $20.5 \%$ of the total corpus and is directly associated to the classes 1 and 2. The words (local, relate, to hygiene, home) were selected by the frequency and values of $x^{2}$ more elevated in this class.

The knowledge of the caregivers presented in this class show the importance to hygiene the ambient and the food and preventive measures to face home infections. The relation between the sanitation and the superficies cleaning showed itself as a concept well assimilated by the caregivers. However the concept of disinfection wasn't understood yet, even being protocols exhaustively worked by the infection control commissions. 
.... when infected in their own homeby lackof caring with the food, hygiene and cleaning.

Ind. 27.

To hygiene the food and house, keep the house clean, to hygiene food, the cleaning is the main way of hygiene and to keep your house and your family far from infection.

Ind.15.

Home infection is when all that the patient use has to be dropped and what is not dropped must be sterilized manually, what I know, is the principal to that the infection no happens, to hygiene the home and disinfect the bathroom and the rest bed.

Ind.79.

The patient safety is defined as the absence of injuries during the care process, and spreads in its contexts the efficient assistance promotion, in opportune time, that is equanimity and founded on the best scientific information and on the integral and individual necessities of the patient and his family [21].

So that can be ensured the control and prevention of home care infections are necessary, besides the inputs/material use of insatiable of contamination and clean ambient, the awareness as for the asepsis principles adoptions with emphasis on the hand sanitation, for application of alcoholicaIly solutions on the situations where there is the lack of infrastructure to the simple cleaning of the hands with water and soap, and the bio security rules [22].

Actually a increasing number of health waste are being generating at home and the guidelines absence or technical orientation and legal regarding them is favor to the packaging and inadequate final disposition, putting in risk the community health and contributing to the environmental degradation [23]. This fact shows that the health programs shall insert in their routines educational actions as orientation in an individual and collective level, directed to the health promotion.

\section{Axis 2 - The concept of home infection to the caregiver, containing 2 classes Class 1: The disease related to the daily routine} With $10 \mathrm{ECU}$, that corresponds to $14.7 \%$ of the total corpus and is directly associated to the classes 6 and 2. The words (disease, understand, nothing, hour) were selected by the frequency and values of $x^{2}$ more elevated in this class.

From this class it is possible to understand the relation to the infections presence with the lack of hygiene at the caregiver and patient daily routine. It shows clearly the association with the infection prevention practices during the home hospitalization caring with the nurse, ambient, food hygiene and the care to avoid contact to contaminated superficies and the present routine activities conducted by the caregiver. Through the interviewers speech was established a nexus between the infection presence and the daily lack of hygiene.

The infection occurring in a dirty dusty ambient, the floor completely dirty, the patient stays totally vulnerable to any kind of respiratory disease, the flu or even a pneumonia... The place's hygiene is fundamental to the prevention and avoids all kind of diseases... I don't understand, but I thing that keeping the place always clean and airy, bathing the patient, clean or combed, it is good, feed him in each three hours with each plate separated.

Ind.1.

At the meal time and etc, having care with the thing, having a lot of hygiene with everything and all the things.

Ind.21. 
We must keep the patient always clean, when bathing, dry completely and don't let anything wet to avoid infection, because it is in all the parts, caring to the sick patient and not get so close to them, mainly people with the flu, because the patient can be vulnerable.

Ind.51.

Some of the activities that are responsibility of the caregiver in his daily activity, being able to vary conform to the patient necessities: help on the hygiene caring. Stimulate and help on the feeding, help on the locomotion and physical activities, such as: walk, take a sun bath and physical exercises; stimulate leisure and occupational activities, conducting changes of position on the bed and chair, and comfort massages; managing medication, conform the prescription and health team orientation and other situations that were necessary to the life quality improvement and this person's health recovery [24].

It is up to the caregiver the executions of daily life basic activities that evolves actions as feed, dress, bath, mobilize, wander the dependent person among others, well as the daily life instrumental activities, it is, those related to the person capacity to take a life independent of the community [25].

The contamination of places apparently cleans reinforces the possibility to disseminate pathogens, places analyzed as clean superficies; without apparent dirty, making many times to ignore efficient cleaning measures. Patients, objects and many superficies confer the possibility to disseminate pathogens if not observed the due precautions, highlighting the hand hygiene [26].

There is the necessity to the home care organization formulate instruments that normalize the infection control at the $A D$, with the view centered on the user and evolving the familiar panorama singularity trying to break the working fragmented practice [27].

\section{Class 2: The concept of the infection based on the dirtiness}

With $10 \mathrm{ECU}$, corresponding to $14.7 \%$ of the total corpus and is directly associated to the classes 6 and 1. The words (many, dirty, prevent, thing) were selected by the frequency and values of $x^{2}$ most elevated in this class.

In this class is understood that the caregivers construct even that primitively the basic concept of how to acquire the home infection based on the lack of hygiene. A concept focused on the relation dirtiness of the ambient and personal hygiene. This fact that although is very relevant, is much vague in relation to the working processes necessary to a caring free of infection.

Me in the point of view to be something seriously be very careful, that we can kill if we don't take care of them, knowing that not only the infection kills but also the lack of prevention.

Ind.63.

When the person doesn't hygiene and doesn't care of the ambient that helshe lives, they shall prevent to care about our self cleaning and our home, when it doesn't happen, the disease comes. We shall take care of our food, physical and emotional health and have all the hygiene.

Ind.53.

The infection caught at home due to a bad caring with the food, not letting the food bad organized, taking care and being really important to be prevented.

Ind.29.

It is necessary to recognize the actors power evolved on the caring process. The caregiver shall know his role in this process and be aware about their power. The people must be educate and informed to the chronicle health and its possible complications [28]. It is understood that when not including the family in their caring plans, there isn't advance 
on propose of care model guided according to the precepts of the health promotion and the integrality principle [29].

The superficies contamination could be reduced with the hand hygiene before and after contact with the patients and with those. The clarification of the superficies role on the dissemination of the IRAS can provide subsides that favor larger adherence the control measure and policy revision, and also alert to the dissemination ways still underestimated [18].

\section{Conclusions}

The home care caregivers know the relation between the ambient lack of hygiene and food with the infection. Recognize the risks that people they care of are exposed. They report the disease and dirtiness as inherent to the infection concept and recognize the lack of security and quality in their practice. It was possible through this study to observe that the risks to acquire an infection related to the assistance during the home hospitalization compared to the risks of the hospitalization are lower, however they are directly associated to the risks caused by the lack of hygiene on the food, ambient and also the patient handling the equipments.

The caregiver has the perception of the necessity to maintain a clean ambient as infection prevention measure, however this fact does not guarantee a safe care and shows the necessity to invest on the caregivers' capacity and their powdering is an essential action to minimize the infection risks.

From the analyzes of this knowledge it is possible to propose intervention strategy that generate reflexes on the home care problematic, specially to the most dependent patients who needs a safe care to prevent and treat infections related to the health assistance.

\section{References}

1. Brasil. Ministério da Saúde. Portaria No 963 de 27 de maio de 2013. Redefine e Atenção Domiciliar no âmbito do Sistema Único de Saúde (SUS). 2013. 7 p.

2. Valle ARMC. Competências do enfermeiro para ações preventivas na atenção domiciliar com ênfase nos riscos de infecção. Tese de Doutorado. Universidade de São Paulo, Ribeirão Preto; 2013.

3. Fernandes AT, Ribeiro Filho N, Barroso EAR. Conceito, Cadeia Epidemiológica das Infecções Hospitalares e Avaliação CustoBenefício das Medidas de Controle. In: Fernandes AT, editores. Infecção Hospitalar e suas Interfaces na Área da Saúde. São Paulo: Atheneu; 2000.

4. Falsey AR, Hennessey PA, Formica MA, Cox C, Walsh EE. Respiratory syncytial virus infection in elderly and high-risk adults. N Engl J Med. 2005; 352:1749-1759.

5. Pérodeau G, Paradis I, Grenier S, Connor KO, Grenon É. Chronic psychotropic drug use among frail elderly women receiving home care services. J. Women Aging. 2011; 23: 321-341.

6. Brondani CM. Desafios de cuidadores familiares no contexto da internação domiciliar. Dissertação de Mestrado, Universidade Federal de Santa Maria; 2008.

7. Carvalho DP, Toso BRGO, Viera CS. Ser cuidador e as implicações do cuidado na atenção domiciliar. Texto Contexto Enferm. 2015; 24: $450-8$.

8. Camargo BV, Justo AM. IRAMUTEQ: Um Software gratuito para Análise de Dados Textuais. Temas de Psicologia. 2013; 21:51318.

9. Dewaal CS. Safe food from a consumer perspective. Food Control. 2003; 14:75-9.

10. Franco BDGM, Landgraf M. Microbiologia dos alimentos. $1^{\text {a }}$.ed. São Paulo: Editora Atheneu; 2008.

11. Kenneley IL. Infection Control and the home care environment. HHCMP. 2010; 22:195-201.

12. Marques ADB, Branco JGO, Cavalcante RC, Lima TR, Rolim KMC, Amorim RF. Os fatores de risco para infecção no domicilio estudados pela análise de similitude. Rev. Pre. Infec e Saúde. 2015; 1:20-27.

13. Cataneo C, Canini SRMS, Oliveira PT, Hayashida M, Gir E. Avaliação da sensibilidade e da especificidade dos critérios para isolamento de pacientes admitidos em um hospital especializado em oncologia. Rev. Latino-Am. Enferm. 2011; 19:1072-9.

14. Ratti RP, Sousa CP. Staphylococcus aureus meticilina resistente (MRSA) e infecções nosocomiais/Methicillin resistant Staphylococcus aureus (MRSA) and nosocomial infections. Rev. ciênc. farm. básica apl. 2009; 30:9-16.

15. Padoveze MC, Figueiredo RM. O papel da Atenção Primária na prevenção de Infecções Relacionadas à Assistência à Saúde. Rev. esc. enferm. USP. 2014; 48:1137-1144. 
16. Markkanen P, Galligan C, Laramie A, Fisher J, Sama S, Quinn M. Understanding sharps injuries in home healthcare: The Safe Home Care qualitative methods study to identify pathways for injury prevention. BMC public health. 2015; 15:1-12.

17. Campos CVS, Silva KL. Cateterismo vesical intermitente realizado pelos cuidadores domiciliares em um serviço de atenção domiciliar. Rev Min Enferm. 2013; 17:753-62.

18. Metz M, Dias LC. Assitencia domiciliar (home care) e instituições de longa permanência. J. Infect Control. 2013; 2:153-75.

19. Siegel JD, Rhinehart E, Jackson M, Chiarello L. 2007 guideline for isolation precautions: preventing transmission of infectious agents in health care settings. Am J Infect Control. 2007; 35:S65-S164.

20. Pittet $D$, Donaldson L. Clean care is safer care: a worldwide priority. Lancet. 2005; 366: 1246-1247.

21. World Health Organization. 10 facts on patient safety. Genebra (SW): WHO; 2012.

22. Farsi $D$, Zare MA, Hassani $S A$, Abbasi $S$, Emaminaini $A$, Hafezimoghadam P, Rezai M. Prevalence of occupational exposure to blood and body secretions and its related effective factors among health care workers of three Emergency Departments in Tehran. J Res Med Sci. 2012; 17: 656-61.

23. André SCDS, Takayanagui AMM. Orientações sobre o descarte de resíduos gerados em domicílios de usuários de insulina. RBSP. 2015; 39: 105-118.

24. Brasil. Ministério da Saúde. Secretaria de Atenção à Saúde. Secretaria de Gestão do Trabalho e da Educação na Saúde. Guia prático do cuidador/Ministério da Saúde, Secretaria de Atenção à Saúde, Secretaria de Gestão do Trabalho e da Educação na Saúde; 2008.

25. Mascarenhas SHZ, Barros ACT. O cuidado no domicílio: a visão da pessoa dependente e do cuidador. Rev Eletr Enf. 2009; 11:4554
26. Wybo I, Blommaert L, Beer T, Soetens O, Regt J, Lacor P, Lauwers S. Outbreak of multidrug-resistant Acinetobacter baumannii in a Belgian university hospital after transfer of patients from Greece. J. Hosp. Infect. 2007; 67:374-80.

27. Valle ARMDC, Andrade DD, Sousa ÁFLD, Carvalho PRMD. Prevenção e controle das infecções no domicílio: desafios e implicações para enfermagem. Acta paul. enferm. 2016; 29:239-44

28. Bellera $L R$, Vendrell $M B$, Surroca $C B$, Poveda $M$, Méndez PP, Sánchez JJZ. Empoderamiento y poder. Su vinculación en el proceso de cuidar al enfermo crónico en atención primaria/ Empowerment and power: their relationship in the process of caring for the chronically ill in primary care. Rev Enferm. 2014; 37:424-31.

29. Costa SRD, Castro EAB. Autocuidado do cuidador familiar de adultos ou idosos dependentes após a alta hospitalar. Rev. bras. enferm. 2014; 67:979-86.
Publish in International Archives of Medicine

International Archives of Medicine is an open access journal publishing articles encompassing all aspects of medical science and clinical practice. IAM is considered a megajournal with independent sections on all areas of medicine. IAM is a really international journal with authors and board members from all around the world. The journal is widely indexed and classified Q2 in category Medicine. 